\title{
Groundwater Quality Assessment in Selected Niger Delta Communities in Nigeria
}

\section{Nwaichi EO* and James 10}

Department of Biochemistry, Faculty of Science, University of Port-Harcourt, P.M.B. 5323, Rivers State, Nigeria

\begin{abstract}
Owing to the inevitability of man's dependence on water, directly or indirectly and the sensitive nature of the largest Africa's river delta, groundwater samples were collected from three functional boreholes in Gokana, Ogale and Trans-Amadi communities in Rivers State of Nigeria to appraise the suitability of the water samples for end-users. The hydrochemistry, physical property and expressed microbial load, using conventional field and laboratory techniques were assayed. The results gave significant variations in most water characteristics attributable to Petroleum production, Artisanal refining, Illegal tapping, and Industrial activities among others. Physicochemical properties like TSS, DO, $\mathrm{NH}_{3}$, Acidity, Colour, and $\mathrm{pH}$ levels exceeded set limits (Department of Petroleum Resources, DPR and Nigerian Standards for Drinking Water Quality, NSDWQ) for all locations and was comparable to the UNEP's recent report findings on Ogoniland and environment. Also, at $p \leq 0.05$, elevated levels of Benzene, a carcinogen was observed for Ogale water samples. Although the expressed microbial load did not comply with standards for all locations, there was no statistically significant difference $(P \leq 0.05)$ among the three different locations. These are suggestive of groundwater pollution as well as interrelationship with social and health implications.
\end{abstract}

Keywords: Water quality; Microbial load; Ogoniland; Health risk; Contamination; Groundwater

\section{Introduction}

Water is an integral part of life on the planet Earth. Water finds multiple uses in every sector of development like agriculture, industry, transportation, aquaculture, etc.

However, since old times, water has also been used for disposal purposes.

Potable water is the water that has sufficient quality to serve as drinking water. It is an essential ingredient for good health and the socio-economic development of man [1], but it is lacking in many societies. Over large parts of the world, humans have inadequate access to potable water and use sources contaminated with disease vector, pathogens or unacceptable levels of toxins or suspended solids [2]. Such water is not wholesome and drinking or using such water in food preparation leads to widespread acute and chronic illness and constitute a major cause of death and misery in many countries [3].

The major sources of pollution in streams, rivers and underground water arise from anthropogenic activities largely caused by the poor and uncultured living habit of people as well as the unhealthy practices of factories, industries and corporate bodies; resulting in the discharge of untreated effluents and waste. Water ppollution affects not only water quality but could also be dangerous to aquatic life [4]

The natural elements causing water pollution are gases, soil minerals, humic materials, waste created by animals and other living organisms present in water. Contamination of water bodies has increasingly become an issue of serious environmental concern $[5,6]$. Reduction of water borne diseases is a major public health goal in many developing countries.

Catchment protection has been shown to be important to the control of pathogens in drinking water [7]. This in turn reduces reliance to treatment processes to ensure water of acceptable quality. A good example of bacteria found in bore-hole water is coli form bacteria [8].

Direct drinking water sourcing from bore-hole has affordability and availability as key advantage over bottle and sachet water in Gokana, Ogale and Trans-Amadi communities, hence, the high patronage by residents in these communities.

This study therefore seeks to investigate the levels of potential pollutants and needed substances in selected borehole water samples to ascertain their fit-for-purpose. A comparative analysis of these samples by location is also implied.

\section{Materials and Methods}

\section{Sampling}

Groundwater sampling was carried out with bailers that were properly decontaminated between samples to avoid crosscontamination. For the same reason, disposable bailers were used for each location. Each sample was assigned a unique identification number and the exact location was registered. Triplicate samples from existing functional Boreholes in Ogale, Gokana and Trans- Amadi communities were collected using standard techniques. Necessary QA/ QC like transportation of samples in Ice chest coolers, use of analytical grade reagents, use of appropriate samplers and data validation were employed.

\section{Test procedure}

Recommended methods by DPR and Federal Ministry of

*Corresponding author: Nwaichi EO, Department of Biochemistry, Faculty of Science, University of Port-Harcourt, P.M.B. 5323, Rivers State, Nigeria, E-mail: nodullm@yahoo.com

Received January 09, 2012; Accepted March 16, 2012; Published March 19 2012

Citation: Nwaichi EO, James IO (2012) Groundwater Quality Assessment in Selected Niger Delta Communities in Nigeria. J Environment Analytic Toxicol 2:133. doi:10.4172/2161-0525.1000133

Copyright: (c) 2012 Nwaichi EO, et al. This is an open-access article distributed under the terms of the Creative Commons Attribution License, which permits unrestricted use, distribution, and reproduction in any medium, provided the original author and source are credited. 
Environment such as American Society for Testing and Materials (ASTM) and American Public Health Association (APHA) were employed.

For colour determination, Lovibond colour disc was used. Total Dissolved Solids and Total suspended Solids were measured by gravimetric method. Determination of Phenolphthalein Alkalinity, Total Alkalinity, Total Hardness, Acidity and Total Organic Carbon was by Titrimetric Method. Turbidity, Nitrate, Nitrite, Chloride, Fluoride, Total Silica, Barium, Lead, Calcium, Magnesium, and Iron was determined using a portable data logging spectrophotometer (Atomic Absorption Spectrophotometer Hach DR/2010). Specially pre-cleaned glassware was used for organic analyses, and specially pre-cleaned Teflon beakers were used for analysis of metal samples. Benzene was analyzed by a process of chemical extraction, evaporation and measurement through gas chromatograph equipped with a mass spectroscopy (GC-MS)

Nutrient Agar was prepared and ethanol - sterilized for Escherichia coli and Total Coliform assay. The plate was removed after $24 \mathrm{hr}$ and perfect circled colonies were identified as Escherichia coli (E. Coli) and other colonies together with E.coli were counted as the total coliform. All preparation and analysis were carried out in a clean environment.

\section{Statistical Analysis}

Data from the different measurements were subjected to analysis of variance (ANOVA) (one-way and two-way as the case may be). Least significant difference (LSD) was used for comparison between the treatment means. Descriptive statistics were calculated using the SPSS v. 13.0 software package.

\section{Results}

The appearance of all the water samples (Ogale, Gokana and TransAmadi) from the three different locations was clear in accordance to NSDWQ specification. The colour for all water samples was $5 \mathrm{H} . \mathrm{U}$ which was above the DPR limit of $0.5 \mathrm{H}$.U. Odour from Ogale water sample was objectionable, while those of Gokana and Trans-Amadi were unobjectionable. The $\mathrm{pH}$ of the water bodies, did not comply with the NSDWQ limit of 6.5-8.5 and the DPR limit of 6.5-9.2 as shown in Figure 1. The temperature for Trans-Amadi samples fell within the NSDWQ limit of $25^{\circ} \mathrm{C}$ while those of Ogale and Gokana exceeded this set limit (Figure 1).

The Turbidity of the studied water samples complied with the NSDWQ limit of 5NTU and the DPR limit of 50 NTU. Also, Electrical conductivity for all studied samples were below the NSDWQ limit of $1000 \mu \mathrm{s} / \mathrm{cm}$

The chemical properties of the water samples studied are as shown in the Figures 2a-2d. The Iron and Salinity levels were within NSDWQ limits of $0.3 \mathrm{mg} / \mathrm{l}$ and $0.50 \%$ respectively. Observed highest total Alkalinity recorded for the Gokana water samples were below the upper limit by NSDWQ (Figure 2a). The phenolphthalein Alkalinity of the water samples gave $0 \mathrm{mg} / \mathrm{l}$, which is in line with the NSDWQ limit. The Acidity was highest for Ogale samples, and did not comply with NSDWQ range of 4.5-8.2 mg/l. Manganese, Aluninium, Phosphate, Nitrate, and Nitrite levels were within recommended levels. Sulphate levels were $1.00 \mathrm{mg} / \mathrm{l}$ for both Ogale and Trans-Amadi and $4.00 \mathrm{mg} / \mathrm{l}$ for Gokana samples which were within the NSDWQ and DPR limits of $100 \mathrm{mg} / \mathrm{l}$ and $200 \mathrm{mg} / \mathrm{l}$ respectively. The observed levels of Ammonia in the water samples for all locations exceeded the NSDWQ limit of 0 $\mathrm{mg} / \mathrm{l}$.
Selenium, Chromium, Cyanide and Zinc levels gave $0.00 \mathrm{mg} / \mathrm{l}$ which fell within the NSDWQ limit of $0.05 \mathrm{mg} / \mathrm{l}$ for Chromium, $0.01 \mathrm{mg} / \mathrm{l}$ for Cyanide and $3.00 \mathrm{mg} / \mathrm{l}$ for Zinc $(15.0 \mathrm{mg} / \mathrm{l}$ from DPR). Benzene $(\mu \mathrm{g} / \mathrm{l})$ levels of 2200.3, 18 and 29 were observed for Ogale, Gokana and Trans - Amadi samples respectively. Copper, Lead and Cadmium levels were low compared to set limits employed. Barium levels were $2.00 \mathrm{mg} / \mathrm{l}$ for Ogale and $1.00 \mathrm{mg} / \mathrm{l}$ for both Gokana and Trans-Amadi samples. Fluoride levels for all water samples were below the detection limit of the analytical instrument (Figure 2b).

Total Silica and TDS values gave no statistically significant difference $(\mathrm{P} \leq 0.05)$ among samples. Total suspended solids, TSS and Biological oxygen demand, BOD mean levels for all samples did not comply with NSDWQ set limits of $10 \mathrm{mg} / \mathrm{l}$ and $4.0-5.0 \mathrm{mg} / \mathrm{l}$. Total organic carbon, TOC gave significant variations among samples.

Total hardness, Calcium and Magnesium hardness levels complied with limits of 500, 75and $0.2 \mathrm{mg} / \mathrm{l}$ set by NSDWQ. At Gokana and Ogale, the hydrocarbon pollution has reached the groundwater at levels in excess of the Nigerian standards as per the DPR target value of $0.2 \mu \mathrm{g} / \mathrm{l}$ for Benzene. Concentration of Benzene was $0.2 \mu \mathrm{g} / \mathrm{l}, 0.94$

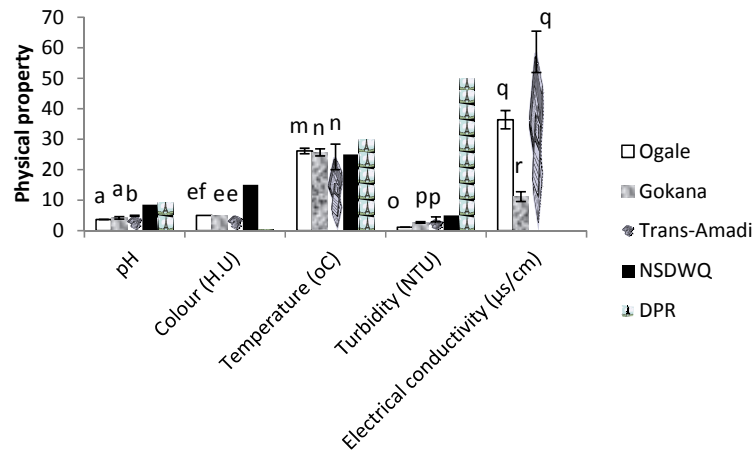

Figure 1: Mean values of physical properties of studied water samples. Bars represent the mean values \pm standard error $(n=3)$ for the studied samples and set standards. Identical superscripts on bars have no significant difference $(P$ $<0.05$ ) between means according to least significant digit.

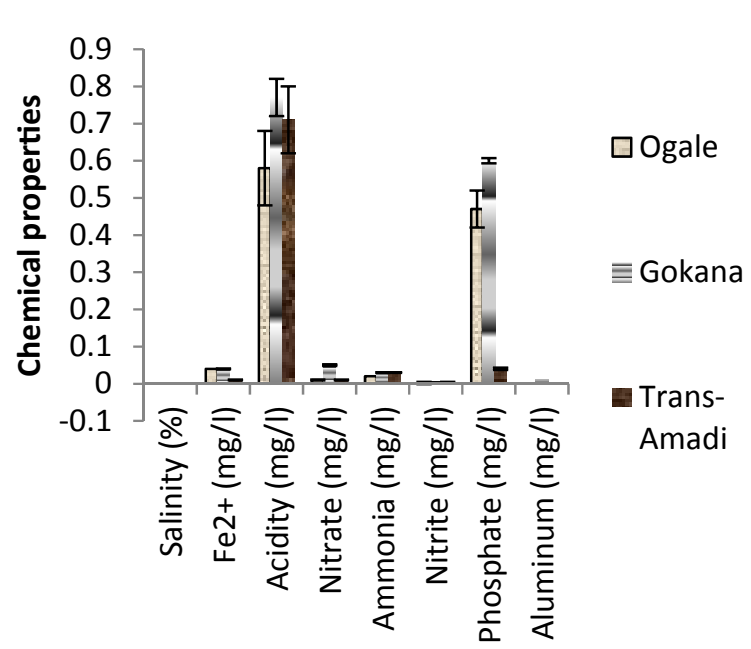

Figure 2a: Mean values of some chemical properties of borehole water samples. Bars represent the mean values \pm standard error $(n=3)$ for the studied samples and set standards. 
$\mu \mathrm{g} / \mathrm{l}$ and $8561 \mu \mathrm{g} / \mathrm{l}$ for Trans - Amadi, Gokana and Ogale respectively. The most serious case of groundwater hydrocarbon contamination was observed at Nsisioken Ogale, in Eleme LGA, close to a Nigerian National Petroleum Company product pipeline where a significant layer of refined oil was observed floating on the groundwater samples and Benzene values exceeding WHO limit of $10 \mu \mathrm{g} / \mathrm{l}$.

The number of Escherichia coli seen per 100ml of the water samples (Ogale, Gokana and Trans-Amadi) ranged from 9-12 cfu/ $100 \mathrm{ml}, 2-4$ $\mathrm{cfu} / 100 \mathrm{ml}$ and $10-19 \mathrm{cfu} / 100 \mathrm{ml}$ respectively while the total coli form ranged from $22-26 \mathrm{cfu} / 100 \mathrm{ml}, 3-7 \mathrm{cfu} / 100 \mathrm{ml}$ and $16-26 \mathrm{cfu} / 100 \mathrm{ml}$ respectively (Figure 3). These exceeded their NSDWQ limit of 0 per $100 \mathrm{ml}$ of sample.

\section{Discussion}

The $\mathrm{pH}$ readings of the water samples varied between 3.54 and 4.97 and was in the order Ogale $>$ Gokana $>$ Trans-Amadi (Figure 1) in increasing acidity. All the samples did not meet the set limits of 6.5-8.5 [9] and 6.5-9.2 (EGASPIN, 2002 [10]. The increased acidity is probably caused by the presence of organic matter in the soil [1]. Acidic waters are favourable to the growth of iron bacteria which cause incrustation of pipes. The objectionable colour resulted from leaching of the organic debris but the colour number has no direct connection with the actual amount of organic material causing the colour [11]. The objectionable odour from Ogale samples is attributable to tank inventory losses,

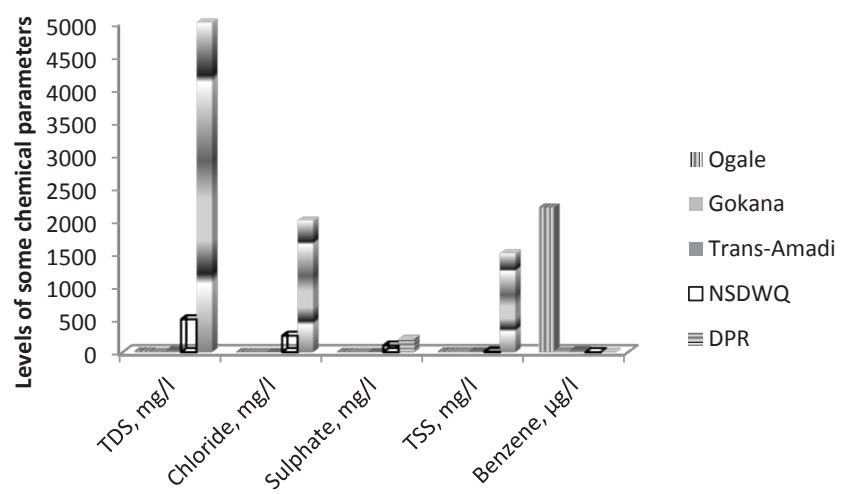

Figure 2b: Mean values of some chemical properties of borehole wate samples. Bars represent the mean values \pm standard error $(n=3)$ for the studied samples and set standard.

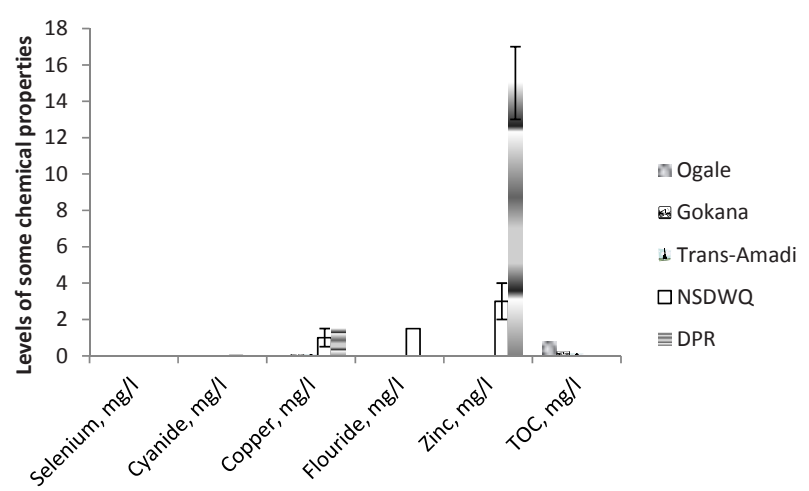

Figure 2c: Mean values of some chemical properties of borehole water samples. Bars represent the mean values \pm standard error $(n=3)$ for the studied samples and set standards.

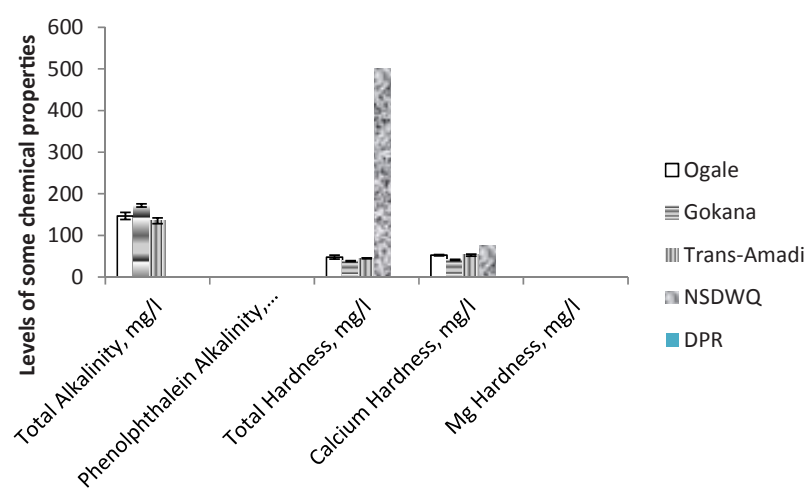

Figure 2d: Mean values of some chemical properties of borehole water samples. Bars represent the mean values \pm standard error $(n=3)$ for the studied samples and set standards.

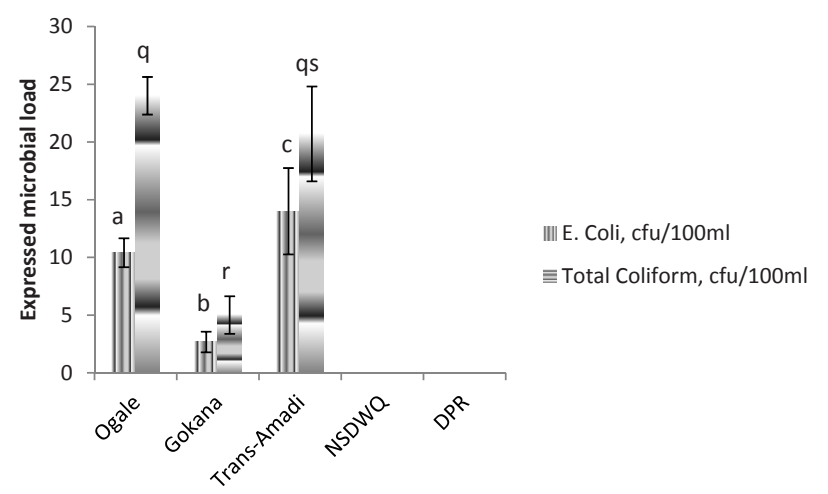

Figure 3: Mean values of some microbiological parameters. Bars represent the mean values \pm standard error $(n=3)$ for the studied samples and set standards. Identical superscripts on bars have no significant difference $(\mathrm{P}<$ 0.05 ) between means according to least significant digit.

spills or leaks from underground storage tanks and deterioration of abandoned tanks and could be treated through leak backup containment, permit compliance and removal of abandoned tanks. The observed trend in temperature may be attributed to increased organic load which according to Alabaster and Lloyd [4] might be acting as a heat insulator, thus lowering the temperature by several degrees at these points. It is necessary to state that the effect of increased temperature depends on the type and level of polluting material [12].

Although turbidity values fell below NSDWQ standards, those of Gokana and Trans - Amadi gave significant values in comparison to set limit of 5NTU (Figure 1). According to Tambari [13], turbidity is caused by a wide variety of suspended and colloidal solids and is a concern to both health and aesthetic reasons and it is a good practice to ensure that water entering the distribution system from a secure groundwater supply has a low turbidity level. Turbidity is effectively reduced through filtration [14]. Although the electrical conductivity, EC for all locations fell below the NSDWQ limit of $1000 \mu \mathrm{s} / \mathrm{cm}$, the mean values were statistically different at the $95 \%$ confidence level. According to Moore (1989) [15], EC estimates the amount of total dissolved solids (TDS) or the total amount of dissolved ions in the water and is controlled by number of factors such as rock types and the wastewater from sewage treatment plants and other sources of ions.

Observed level of Iron in Ogale samples is attributable to the leaching of minerals [1] such as hematite, limonite and goethite. According to 
Margie [16], the present recommended limit of iron in water, $0.3 \mathrm{mg} / \mathrm{l}$, is based on taste and appearance rather than on any detrimental health effects. Alkalinity is an important concept in understanding the effect of the acid rain. Total and Phenolphthalein alkalinity values were low giving rise to high acidity values of the samples (Figure 2a). According to Hem [11], a major factor in producing strongly acid water in many areas is the oxidation of sulfide minerals exposed to the air by mining operations. In some of these areas, natural sediments at or near the surface contain enough reduced minerals to lower the $\mathrm{pH}$ of the natural run-off significantly. Another factor is the acid rain; the rain or any form of precipitation that is unusually acidic, meaning that it possesses elevated levels of hydrogen ions (low pH) [17]. According to Saad [18], the adverse effects of such occurrence are on plants, aquatic animals and infrastructure through the process of deposition. Acid rain is caused by emissions of Sulfur dioxide and Nitrogen oxides which react with the water molecules in the atmosphere to produce acids. Although Manganese levels were low, possible biomagnification is not ruled out. Manganese is an essential element for both plants and animals but a recent research by Maryse [19] reported that high concentration of Manganese causes adverse effects on children's intellectual abilities. Nitrates and Nitrites with highest concentration in Gokana samples fell below the NSDWQ set standard of 50mg/l. According to Vermont Department of health [20], high concentration of Nitrate and Nitrite can cause methemoglobinemia (a blue baby syndrome) and formation of a chemical called Nitrosamine in the digestive tract. Observed high Ammonia levels is quite objectionable. Although Ammonia is a key metabolite in mammals, it has a toxic effect on humans only if the intake becomes higher than the capacity to detoxify, which could cause an increase in the brain's water content (cerebral edema) [21].

According to Alabaster [4], animals obtain their phosphate in water and plant mineral. Phosphate levels in the three water samples fell within the set standard for drinking water. Sources of Phosphate include human sewage, agricultural run-off from crops, sewage from animal feedlots, pulp and paper industry etc. Aluminum was only detected in trace amount. Investigation of the levels of metals revealed up to $2 \mathrm{mg} / \mathrm{l}$ of Barium, $0.01 \mathrm{mg} / \mathrm{l}$ of Copper and $0.009 \mathrm{mg} / \mathrm{l}$ of Lead for Ogale, Gokana and Trans-Amadi borehole water samples respectively. Barium is a heavy metal and excessive uptake of water-soluble Ba may cause a person to experience vomiting, abdominal cramps, diarrhea, difficulties in breathing, increased or decreased blood pressure, numbness around the face, and muscle weakness [22]. Barium chemicals are used by the oil industry in drilling mud, which is then often left in the mud pits around wellheads or dumped offshore [23]. Selenium, Chromium, Zinc and Cadmium gave zero (0) values at all locations (Figure $2 \mathrm{~b}$ ). These values fell below the set standard of $0.05 \mathrm{mg} / \mathrm{l}, 3 \mathrm{mg} / \mathrm{l}$ and 0.003 for Chromium, Zinc and Cadmium respectively. FEPA [24] has reported that Copper can potentially cause severe health effects such as gastrointestinal disturbance including nausea and vomiting. Use of water that exceeds the set standard for many years could cause liver or kidney damage. Mean value of $0.01 \mathrm{mg} / \mathrm{l}$ was recorded in Gokana and Trans - Amadi samples. Lead levels fell above the set limit of $0.001 \mathrm{mg} / 1$ (EGASPIN, 2002) and could have some health implications within the communities. According to NCEH [25], Lead found in borehole water usually comes from the corrosion of older fixtures or from the solder that connects pipes and when water sits in Lead pipes for several hours, leaching into water supply is inherent. Lead affects every one of the body's organ systems, especially the nervous system, renal system, cardiovascular system and reproductive system. High levels of observed Benzene in Gokana and Ogale samples is attributable to no continuous clay layer across Ogoniland, exposing the groundwater (and beyond) to hydrocarbons spilled on the surface [26]. Natives at Nsisioken Ogale are drinking water from boreholes/ wells that are contaminated with Benzene, a known carcinogen, at levels over 11000 and 850 times above the EGASPIN target value $(0.2 \mu \mathrm{g} / \mathrm{l})$ and World Health Organization $(\mathrm{WHO})$ guidelines $(0.2 \mu \mathrm{g} / \mathrm{l})$ respectively. This is most worrisome and warrants emergency remedial action. Benzene also has numerous short - term effects. Chloride levels all samples fell below the set standard of $250 \mathrm{mg} / \mathrm{l}$ [9]. According to Paul [27], Chlorine itself is not believed to be the problem; scientists suspected that the actual cause of bladder cancer is a group of chemicals that form as a result of reactions between the Chlorine and natural substances and pollutants in the water (organic matter such as leaves and twigs). The hardness values for groundwater samples in this study ranged from 37.6-52.0mg/l. According to FEPA [24], hardness range of $0-60 \mathrm{mg} / 1$ shows soft water. In terms of total hardness, therefore, the water samples could be suitable for domestic purposes such as cleaning because it will lather easily with soap. Acceptable total dissolved solids (TDS) levels of 4.8 to $27.2 \mathrm{mg} / \mathrm{l}$ could be attributed to the depth of the boreholes. Low Dissolved Oxygen levels ranging from $1.1-1.7 \mathrm{mg} / \mathrm{l}$ is indicative of organic pollution. This shows that the amount of Oxygen saturation is very low. Total Organic Content was highest in Ogale samples and least in Trans-Amadi samples. Organic matter exists in ground and surface water due to biological decomposition. Leaves and grasses for instance form methane gas as a decomposition by-product, and animal decay produces both fulvic and humic acids. Escherichia coli (E. coli) and Total coli form were detected in the three water bodies (Figure 3). Trans-Amadi has the highest number of E.coli with an average value of $14 \mathrm{cfu}$ per $100 \mathrm{ml}$ of the samples. This may have arisen due to dense industrial activities in the area. Gokana gave the lowest number of E.coli (2-4 cfu per $100 \mathrm{ml}$ sample) as well as total coliform ranging from 3-7 cfu per $100 \mathrm{ml}$ of the samples. Highest coliform load were expressed in Ogale water samples. This may be attributed to microbial hydrocarbon degraders in this area as hydrocarbon contamination is evident. Also, at 95\% confidence level, there was statistically significant difference among all microbiological parameters studied.

\section{Conclusions}

From the foregoing, it has become imperative that all borehole water samples studied are organically polluted and at such proper aeration and disinfection should be applied to improve the water quality. Levels of some metals like Barium in Ogale samples summon public health concerns for the community. Further studies on contaminants mobility and fate, soil characteristics and effective monitoring around contaminated sites is implied bearing in mind the dose and exposure time.

\section{References}

1. Udom GJ, Ushie FA, Esu EO (2002) A Geochemical Survey of Groundwate in Khana and Gokana Local Government Area of Rivers State, Nigeria. J Appl Sci Envi Manag 6: 53-59.

2. Sobsey MD (1990) Inactivation of Health Related Microorganism in water by Disinfection processes. Water Sci Technol 21: 179-195.

3. Power KN, Nagy LA (1989) Bacterial Regrowth in water supplies. University press Cambridge 196-204.

4. Alabaster JS, Lloyd R (1980) Water quality criteria for fresh fish. Butter worths London, 1-283

5. Hodges L (1980) Environmental Pollution. $2^{\text {nd }}$ Ed. Holt Rincheart and Winston Publications, New York, 98-109.

6. Akaninwor JO,Wegwu MO, Nwaichi EO (2007) Levels of Some Heavy Metals and Physico Chemical Properties of Effluents from a Beverage Company in Rivers State, Nigeria. J Appl Sci Envi Manag 11: 27-30. 
Citation: Nwaichi EO, James IO (2012) Groundwater Quality Assessment in Selected Niger Delta Communities in Nigeria. J Environment Analytic Toxicol 2:133. doi:10.4172/2161-0525.1000133

Page 5 of 5

7. LeChevallier MW, Abbaszadegan M, Camper K, Hurst CJ, Izaguirre G, et al. (2001) Committee Report On Emerging Pathogens-Bacteria. J Ame Works Ass 91: 101-109.

8. Cowon ST (2003) Cowon and steel's Manual for Identification of Bacteria. $2^{\text {nd }}$ Ed, University Press Cambridge, 252-272.

9. NSDWQ (2007) Nigerian Standard for Drinking Water Quality. Revised Ed 6775.

10. EGASPIN (2002) Environmental guidelines and Standards for the Petroleum Resources. Revised Ed 314.

11. Hem JD (1985) Study and Interpretation of Chemical Characteristics of natura water. US Geological Survey Water-Supply Paper 2254: 11-263.

12. Brown VM, Jordan DHM, Tiller BA (1967) The effect of temperature on the acute toxicity of phenol to rainbow trout in hard water. Water Research 1: 587 594

13. Tambari GL (2007) Water and Waste water Engineering. Pearl publishers 13.

14. Health Canada (1986) Effect of Turbidity in Water. Retrieved on 14th June, 2011.

15. Moore ML (1989) NALMS Management guide for Lakes and Reservoirs. North American lake Management society 53: 705-5443.

16. Margie D (2003) Public water section.

17. Nwaichi EO, Uzazobona MA (2011) Estimation of the CO2 Level due to Gas Flaring in the Niger Delta. Research J Environ Sci 5: 565-572.
18. Saad MAH (1978) Seasonal Variation of some physic-chemical conditions of shattal- Arab Estuary, Raw, Estuarine, coastal Marine Science 6: 503-513.

19. Maryse B (2010) Intellectual Impairment In School-Age Children Exposed to Manganese. J Env Health persp.

20. Vermont Department of Health (2005). Nitrates in water. Retrieved on $11^{\text {th }}$ of June, 2011.

21. Nelson LD, Cox MM (2008) Principles of Biochemistry. $5^{\text {th }}$ Ed, Freeman and Co, New York 65-66.

22. The Agency for Toxic Substances and Diseases (TATSD), National Center for Environmental Health (2008) Public Health Statement for Barium.

23. Olsgard F, Gray JS (1995) A comprehensive analysis of the effects of offshore oil and gas exploration and production on the benthic communities of the Norwegian continental shelf. Mar Ecol Prog Ser 122: 277-306.

24. Federal Environmental Protection Agency, FEPA (2005) Guidelines and Standards for Environmental Pollution Control in Nigeria. 552: 46-55.

25. NCEH (2010) National Centre for Environmental Health. Disease Control and Prevention.

26. UNEP (2011) United Nations Environmental Progranme Report. Environmenta Assessment of Ogoniland 94-200.

27. Paul D (1987) Health effects of Chlorine in Drinking water. Pure Earth Technologies Inc. 